\title{
Movement Analysis of Lay Up Basketball
}

\author{
Ade Ros Riza ${ }^{1}$, Indra Kasih ${ }^{2}$, Zulpikar $^{3}$ \\ \{aderosriza@yahoo.com ${ }^{1}$, \\ indrakasih@gmail.com² zulpikarilaham@yahoo.com $\left.{ }^{3}\right\}$ \\ Pendidikan Kesehatan Jasmani dan Rekreasi, Universitas Negeri Medan, Jl. Willem Iskandar Psr V, \\ Medan, Indonesia ${ }^{1,2,3}$
}

\begin{abstract}
This research aims to know the common mistakes made when doing a lay up shot in the game of basketball. Analysis of lay up shot is very necessary for the coach or instructor and basketball player itself to figure out how to fix the error. Analysis of lying Shot started, step (1. Reflecting sphere of the Agency towards the ring, 2. Forward with the right foot), jump (jump using the left foot), shot (1. Insert the ball with your right hand, 2. Thighs lift your right leg, 3 . Head the ball to the target on the reflection). The number of samples as many as 35 people, who came from rookie basketball player i.e. students aged 17-19 years. The results of this research are (1) stepped on stage just as much as $44.3 \%$ to successfully perform the phases correctly. (2) at the stage of jumping as much as $77.1 \%$ to successfully perform this stage well and (3) on the stage of entering the ball just as much as $41 \%$ who succeed do the phases correctly.
\end{abstract}

Keywords: Basketball, Lay Up Shot, Movement Analisys

\section{Introduction}

Basketball is one of the most popular sports in the world that his fans came from all ages felt that basketball is fun, competitive sports, educate, entertain and, salubrious, individual skills like shots, bait, dribel, and rebound, as well as team work to invade or survive is the prerequisite to succeed in playing this sport (Oliver, 2007:1).

The game of basketball is aiming to get the value of running mates with how to insert the ball into the opponent's basket and keep their own basket from the entry of the ball from an opponent. As mentioned by Wissel, (1996:2) that "the aim of the game of basketball is gaining value (score) by inserting the ball into the opponent's basket and prevent other teams do the same thing."

One of the techniques that must be mastered by students in the game of basketball is a technique lay up shoot. This technique is the easiest technique to obtain the numbers so that can go on the purpose of the game of basketball itself.

This research aims to know the common mistakes done by a novice at the time lay up shot in the game of basketball. Analysis of lay up shot is very necessary for the coach or instructor and basketball player itself in order to find out how to fix the error. Analysis of Lay Up Shot starts from, step (1. Bounce the ball near the agency headed to the ring, 2. Forward with the right foot), jump (Jump using the left foot), 3. Place the balls (1. Insert the ball with your right hand, 2. Thigh lift right foot, 3. Redirect the ball into the goal box in the Board of reflection).

Oliver (2007:20) States, "lay up is most likely shot high to print numbers in basketball, the players must try to do a assailant lay up in a game". 
In doing shots lay up much-needed presence of accuracy in directing the ball into the basketball hoop. According to Wissel (2000:44), "the basic skills that should be trained in lay up shot is accuracy in shooting". One of the decisive factors to produce an accurate shot is the angle of the shot.

As for the several stages of a lay up shot in the game of basketball, among others:

1. Dribble close to the basket with your right hand.

Since you're doing a right-handed lay up, angle your approach toward the right side of the basket. You want to get close enough to have easy access to the basket, but not so close that you end up directly under it. Lay ups are often taken off of a running dribble. Practice approaching the basket slowly at first, and increase your speed once you've got the footwork down. You can do a right-handed lay up if you're starting near the center or right side of the basket. If you're approaching the basket from the left, you'll want to do a left-handed lay up.

2. Step toward the basket with your right foot.

When you're just a few feet from the basket, take a step toward it with our right foot. Use this step to gain distance and position yourself within easy shooting range. Dribble the ball one last time just outside your right foot.

3. Jump off of your left foot.

As soon as your left foot lands, use it to jump in the direction of the basket. Your body should be moving toward the basket, but don't lean forward. Ideally, you'll be positioned close enough to the basket that you can jump straight up to take your shot. As you jump, bring the ball out of the dribble to your chest to prepare for the shot.

4. Shoot with your right arm as you lift your right leg.

As you jump, imagine a string attached to your right arm and your right leg. Move them at the same time as you shoot, as though someone were pulling upward on the string. Your right knee should be bent and pointed toward the basket while your right arm moves up to shoot the ball. Arch your arm toward the basket. Shoot with your elbow slightly bent, so that your arm looks like the neck of a swan.

When you're doing a lay up, the shooting technique is slightly different from that of a regular shot. Instead of using your left hand to steady the ball, you want to shoot the ball using only your right hand. This gives you more reach, and since you're so close to the basket that it's difficult to miss the shot, you don't really need your left hand to steady the ball. As you shoot, slightly rotate your wrist inward to give the ball a little bit of spin, rather than snapping your wrist forward as you would for a regular shot. The gentle spin will keep it from hammering off the rim or backboard with too much force.

5. Aim for the sweet spot on the backboard.

One of the reasons a lay up is such a sure bet is because you can always use the backboard to help ease the shot into the basket. When you're doing a right-handed lay up, the sweet spot is slightly to the right of the square in the center of the backboard. This spot absorbs the impact of the ball and drops it right down through the net.

You'll get two points no matter how you make your shot, but it's better to aim for the backboard instead of trying to just tip the ball over the rim. The backboard allows more room for error, but if you hit the rim funny the ball will bounce right out. There's nothing worse than missing a wide-open lay up when you have full access to the basket, so work on hitting that sweet spot every time. 


\section{Material and Methods}

In this reasearch, the authors use a suitable research methods with the purpose of this research, qualitative research. The number of sample as many as 35 people, who came from a basketball player the beginner students aged 17 to 19 years.

The collection of data used in this research is to use the tests. And tests that will be used is a test of a lay up shot (Sodikun, 1992:125).

Objective: to measure the skill shot lay up. Equipment: a set of boards, basketball, basketball court, whistles and basketball.

Hint: the Testee is in the middle of the field, while holding the right side of the ball. Dribble himself headed to the basketball and do shots lay up.

\section{Result}

The results of this research are (1) stepped on stage just as much as $44.3 \%$ to successfully perform the phases correctly. (2) at the stage of jumping as much as $77.1 \%$ to successfully perform this stage well and (3) on the stage of entering the ball just as much as $41 \%$ who succeed do the phases correctly.

Table 1: Analysis Lay Up Shot Basketball

\begin{tabular}{cccccc}
\hline \multicolumn{7}{c}{ Lay Up Shoot Movement } \\
\multicolumn{1}{c}{ Step } & Jump & & Shot & \\
$\sum_{\text {ind }}$ & $\sum_{1}$ & & & & \\
1 & 2 & $\sum$ ind 1 & $\sum$ ind 1 & $\sum$ ind 2 & $\sum$ ind 3 \\
8 & 23 & 27 & 26 & 11 & 6 \\
Evarage= & Evarage= & & & \\
$44,3 \%$ & $77,1 \%$ & & Evarage $=41 \%$ & \\
\hline
\end{tabular}

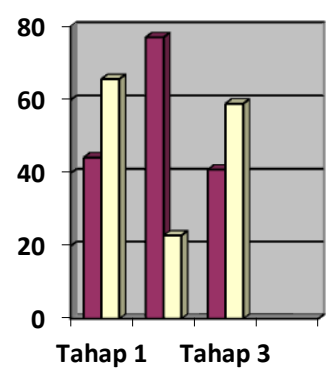

Dilakukan

口Tdk Dilakukan 


\section{Conclusion}

From the results of the data analysis above, it can be concluded that the stages of step and jump had a lower score, while entering stage tend to be higher.

So from the above analysis we can know, of the three stages we can start and stressed an exercise program or learning that we should start first. We can create a form of exercise or learning in accordance with the results of the analysis and to give priority to three stages.

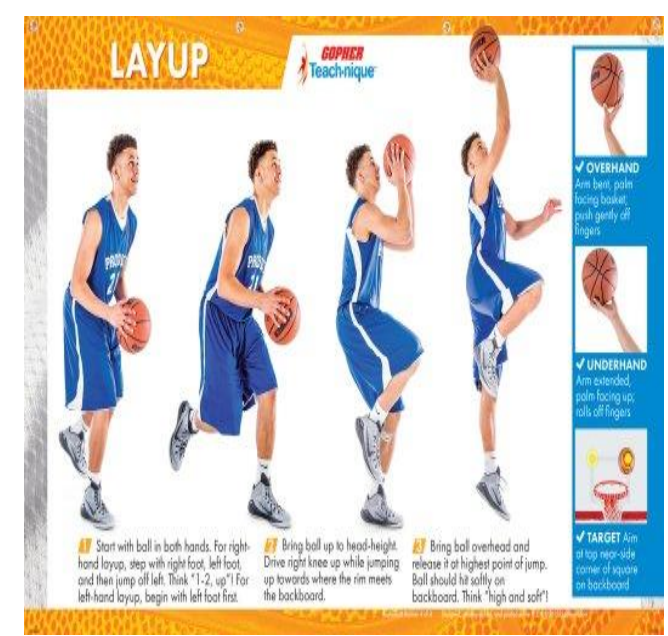

\section{References}

[1]Adams, R. M.: The "hot hand" revisited: Successful basketball shooting as a function of intershot interval. Perceptual and Motor Skills, 74, 934. Google Scholar, SAGE Journals, ISI (1992)

[2]Gilovich, T., Vallone, R., Tversky, A.: The hot hand in basketball: On the misperception of random sequences. Cognitive Psychology, 17, 295-314. Google Scholar, Crossref, ISI (1985)

[3]Hopkins, D.R., J. Shick, and J.J. Plack. Basketball for Boys and Girls. Skills Test Manual. Reston, VA: American Alliance for Health, Physical Education, Recreation and Dance, (1984)

[4] Braian J. Reich.: A Spatial Analisis Of Basketball Shot Cart Data. The American Statistician. Vol. 60, No. 1 February (2006)

[5] Kornecki S, Lenart I, Siemieński A.: Dynamical analysis of basketball jump shot. Biol Sport.Vol 19,No1: 73-90 (2002)

[6]Oliver, J.: Dasar-dasar Bola Basket. Bandung: Pakar Raya (2007)

[7] Sodikun.: Tes Keterampilan Bola Basket. Bandung: Pakar Raya (1992)

[8] Wissel, Hall.:Bola Basket Dilengkapi dengan Program Pemahiran Tekhnik dan Taktik. Jakarta: PT. Raja Grafindo Persada. (2000) 